\title{
ANALISIS KETERAMPILAN TEKNIK DASAR PASSING DALAM SEPAK BOLA
}

\author{
Nugroho Priyo Utomo ${ }^{1}$, Pungki Indarto ${ }^{2}$ \\ Email : $\underline{\text { A810170023@student.ums.ac.id }}{ }^{1}$, pi311@ums.ac.id ${ }^{2}$ \\ 1,2 Program Studi Pendidikan Olahraga Fakultas Keguruan Ilmu Pendidikan Universitas \\ Muhammadiyah Surakarta
}

\begin{abstract}
Abstrak
Tujuan dari penelitian ini adalah untuk mengetahui tingkat keterampilan teknik dasar passing dalam sepakbola. Penelitian ini ialah penelitian deskriptif kuantitatif dengan menggunakan metode survei serta teknik pengumpulan data pada penelitian ini menggunakan teknik tes dan pengukuran. Variabel pada penelitian ini ialah variabel tunggal yaitu keterampilan teknik dasar passing dalam sepakbola. Populasi yang dipergunakan merupakan semua siswa puslat Pandanaran Boyolali yg berjumlah 72 siswa. Terdiri dari KU-14 yang berjumlah 49 siswa serta KU-16 yang berjumlah 20 siswa. Sampel yang digunakan pada penelitian ini ialah siswa KU-14 diambil 20 siswa dengan cara purposive sampling. Instrument tes pada penelitian ini berupa indikator-indikator dari penilaian keterampilan passing bola yang indikatornya ialah sikap awal, pelaksanaan, sikap akhir, dan hasil. Hasil penelitian ini adalah tingkat keterampilan teknik dasar passing dalam permainan sepakbola siswa Puslat Pandanaran Boyolali dalam kategori cukup, hal ini selaras dengan capaian yang diperoleh oleh siswa yaitu pada kategori baik sekali memiliki presentase $20 \%$, kategori baik presentase $5 \%$, kategori cukup presentase $30 \%$, kategori kurang presentase $40 \%$, dan kategori kurang sekali $5 \%$.
\end{abstract}

Kata Kunci: Analisis keterampilan; Tehnik dasar pasing.

\begin{abstract}
The purpose of this study was to determine the level of basic passing technique skills in football. This research is a quantitative descriptive study using survey methods and data collection techniques in this study using test and measurement techniques. The variable in this study is a single variable, namely basic passing technique skills in football. The population used is all students of the Pandanaran Boyolali Center, totaling 72 students. It consists of KU-14 which consists of 49 students and $\mathrm{KU}-16$ which consists of 20 students. The sample used in this study was KU-14 students taken by 20 students by purposive sampling. The test instrument in this study was in the form of indicators of the assessment of ball passing skills, the indicators of which were initial attitude, implementation, final attitude, and results. The results of this study are the level of basic passing technique skills in the soccer game of Puslat Pandanaran Boyolali students in the sufficient category, this is in line with the achievements obtained by students, namely in the very good category having a percentage of $20 \%$, good category 5\% percentage, moderate category 30\%, 40\% less category, and 5\% less category.
\end{abstract}

Keywords: Skills analysis; Basic passing technique.

\section{A. Pendahuluan}

Salah satu faktor pendukung untuk meningkatkan kualitas sumber daya manusia adalah dengan melalui olahraga. Olahraga di kehidupan manusia pada umumnya sangat 
berpengaruh, karena dengan adanya olahraga manusia dapat meningkatkan kebugaran tubuh dan menjaga kesehatan. Selain untuk menjaga kondisi kebugaran tubuh, olahraga juga dapat digunakan sebagai ajang memperoleh prestasi, maka dari itu olahraga sangat membutuhkan perhatian dan pembinaan khusus dalam usaha mencari bibit baru dan meningkatkan prestasi atlet. Semua cabang olahraga membutuhkan kemampuan penguasaan teknik, taktik, strategi, mental, serta sarana dan prasarana penunjang dalam latihan maupun permainan. Cabang olahraga yg paling digemari dikalangan masyarakat pada saat ini yaitu sepakbola. Sepakbola merupakan salah satu olahraga permainan bola besar yang dimainkan secara beregu yang saling berhadapan dan membutuhkan kesolidan tim untuk memperoleh permainan yang bagus(Unnithan et al., 2017). Untuk menciptakan suatu permainan yang bagus dalam permainan sepakbola membutuhkan penguasaan teknik dasar sepakbola, teknik dasar permainan sepakbola antara lain yaitu passing (teknik mengoper bola), control (teknik menghentikan bola), dribbling (teknik menggiring bola), shooting (teknik menendang atau menembak bola dengan keras ke gawang lawan), heading (teknik menyudul bola), intercepting (teknik merebut bola), sliding tackle (teknik menyapu bola), throw in (teknik lemparan ke dalam), goal keeping (teknik menangkap bola), dan juggling (teknik menimang bola untuk melatih kontrol bola) (Indarto, 2019). Karena kemampuan teknik dasar sepakbola adalah modal utama seseorang untuk bermain sepakbola, maka untuk memperbaiki dan meningkatkan kualitas di dalam prestasi permainan sepakbola, permasalahan teknik menjadi faktor penentu permainan sepakbola(Soniawan \& Irawan, 2018).

Passing merupakan salah satu teknik dasar bermain sepakbola yang sangat komplek atau penting yang sering kali dilakukan dalam permainan sepakbola dan sebagian besar permainan sepakbola dilakukan dengan passing. Pada dasarnya teknik dasar passing berguna untuk mengoperkan bola kepada teman atau menghubungkan bola pemain satu ke pemain lain dalam usaha untuk membangun serangan kemudian mencetak gol. Karena tujuan utama dari permainan sepakbola sendiri yaitu memenangkan pertandingan dengan mencetak gol sebanyak-banyaknya ke gawang lawan. Untuk meningkatkan kemampuan penguasaan teknik dasar passing dalam sepakbola, latihan sangat berpengaruh terhadap kualitas penguasaan teknik dasar untuk memperoleh sebuah prestasi, menurut (Arwandi \& Ardianda, 2018) upaya untuk peningkatan prestasi pada pemain sepakbola yaitu dengan latihan, latihan adalah salah satu faktor yang sangat menentukan dalam pencapaian prestasi seseorang dan bentuk dari latihan tersebut yaitu sesuai dengan target yang akan dicapai. Puslat Pandanaran Boyolali merupakan pembinaan lanjutan yang dilakukan oleh SSB Pandanaran Boyolali sebagai wadah pembinaan pada pesepakbola di boyolali KU-14 dan KU-16, karena di SSB Pandanaran Boyolali memfasilitasi pemain berusia sekolah dasar yaitu dibawah 12 tahun yang dimana pada anak dibawah 12 tahun masih pada fase kegembiraan. Puslat Pandanaran Boyolali didirikan oleh Bapak Ahmad Arif dan dibantu oleh beberapa tokoh sepakbola di boyolali dan diresmikan langsung oleh Bapak Drs. Seno Samudro yang dimana sebagai pelindung dari Puslat Pandanaran Boyolali tersebut. Puslat Pandanaran Boyolali sendiri sudah terdaftar dalam PSSI Boyolali dan pada saat ini masih dalam proses untuk melegalkan secara notaris dan kemenkumham.

Homebase dari Puslat Pandanaran Boyolali yang awalnya di stadion Pandanaran Boyolali kini berpindah di lapangan Bangsalan Teras Boyolali, karena stadion Pandanaran Boyolali kondisinya pada saat ini akan dibuat pasar, maka dari itu pak Arif selaku penanggungjawab Puslat Pandanaran Boyolali mengarahkan untuk memaksimalkan lapangan yang ada terlebih dahulu. Di dalam Puslat Pandanaran Boyolali terbagi menjadi dua pengelompokan sesuai dengan kelompok usia yaitu KU-14 dan KU-16. Prestasi yang dimiliki Puslat Pandanaran Boyolali terbilang cukup membanggakan yang dimana pada pagelaran liga top skor regional JATENG-DIY menempatkan Puslat Pandanaran diperingkat ketiga. Selain itu Puslat Pandanaran Boyolali pada tahun 2017 juga menjuarai piala Menpora Jawa Tengah 
setelah itu maju ke Nasional dan masuk 8 besar nasional. Siswa Puslat Pandanaran Boyolali memiliki tingkat keterampilan passing yang berbeda-beda hal ini dikarenakan ada beberapa faktor yang mempengaruhi tingkat keterampilan passing salah satunya yaitu impact atau perkenaan kaki pada bola dan hal tersebut perlu diperbaiki kaitannya dengan passing karena pada permainan sepakbola passing sangatlah berpengaruh terhadap jalannya permainan maka dari itu passing merupakan dasar yang harus ditekankan, dilakukan, dan harus diulang-ulang untuk memperoleh hasil yang maksimal. Selain impact faktor yang mempengaruhi passing yaitu kualitas lapangan, kualitas bola dan secara khusus otot power pada siswa Puslat Pandanaran Boyolali juga sangat berpengaruh terhadap kualitas passing karena mendukung pada tekanan yang diberikan pada bola. Dan untuk Puslat Pandanaran Boyolali belum pernah dilakukan tes keterampilan teknik dasar passing, karena pelatih mengevaluasi menurut pengamatan pada saat di lapangan saja.

Berdasarkan permasalahan yang sudah diuraikan diatas maka penulis merumuskan penelitian yang berjudul "Analisis Keterampilan Teknik Dasar Passing Dalam Permainan Sepakbola Di Puslat Pandanaran Boyolali”. Yang dimana Analisis merupakan penyelidikan terhadap suatu peristiwa untuk mengetahui keadaan yg sebenarnya, analisis umumnya di aplikasikan dalam berbagai keadaan dan lingkungan yg berbeda-beda, karena dengan adanya analisis bisa membantu memudahkan untuk mengetahui secara lebih jelasnya suatu kalimat atau istilah. Menurut (Satori, n.d.) analisis merupakan suatu usaha untuk mengurai suatu persoalan atau fokus kajian menjadi bagian-bagian sehingga susunan/tatanan bentuk sesuai yang diurai itu tampak dengan jelas dan karenanya mampu secara lebih jelas ditangkap maknanya atau lebih jernih dimengerti duduk perkaranya. (Komarudin, 2017) Mendefinisikan analisis menjadi suatu tindakan berfikir dalam mengklarifikasikan satu keseluruhan yang koheren menjadi komponen-komponen yang lebih kecil, dengan maksud untuk mengenal hubungan setiap komponen, tanda-tanda komponen, dan fungsi dari masingmasing komponen. (Hetrina et al., 2020) Mengartikan istilah analisis sebagai suatu aksi memerinci suatu subjek/objek tertentu menjadi beberapa bagian. Setiap bagian tersebut diamati, kemudian dicari hubungannya dengan bagian lain yg terhubung, dengan tujuan mendapatkan definisi yang tepat dan supaya praktis dipahami secara keseluruhan.

\section{B. Metode}

Penelitian ini ialah penelitian deskriptif kuantitatif yg dimana didalam penelitian ini peneliti hanya mendeskripsikan situasi yg sedang terjadi waktu ini. Metode yg dipergunakan pada penelitian ini ialah metode survei, sedangkan teknik pengumpulan data pada penelitian ini menggunakan teknik tes dan pengukuran. Instrument penelitian pada penelitian ini merupakan modifikasi dari Buku Sepakbola Menurut (Joseph \& Agusta, 2016) yang dimana pada pelaksanaan tes dan alat itu berupa indikator-indikator dari penilaian keterampilan passing bola yang indikatornya adalah sikap awal, pelaksanaan, sikap akhir, dan hasil yang sudah divalidasi oleh ahli. Penelitian dilaksanakan pada hari Minggu tanggal 30 Mei 2021 di lapangan desa Bangsalan, Kecamatan Teras, Kabupaten Boyolali. Populasi yang digunakan dalam penelitian ini adalah seluruh siswa Puslat Pandanaran Boyolali yaitu 72 siswa, yang dimana KU-14 terdapat 49 siswa dan KU-16 terdapat 23 siswa. Sampling yang dimana teknik penentuan sampel ini dengan pertimbangan dan dipilih sesuai dengan kemampuan. Kriteria untuk sampel yang digunakan yaitu pemain yang masih aktif, pemain KU-14, dan rekomendasi dari pelatih. Maka dengan kriteria tersebut didalam penelitian ini menggunakan 20 orang siswa Puslat Pandanaran Boyolali sebagai sampel. 


\section{Hasil dan Pembahasan}

Hasil penelitian analisis keterampilan teknik dasar passing dalam permainan sepakbola di Puslat Pandanaran Boyolali diperoleh 20 siswa yang dijadikan sebagai sampel penelitian. Dari hasil penelitian tersebut akan dideskripsikan dalam bentuk tabel sebagai berikut:

Tabel 1. Deskripsi Statistik Hasil Penelitian Keterampilan Passing Dalam Permainan Sepakbola Di Puslat Pandanaran Boyolali

\begin{tabular}{lc} 
Statistik & Skor \\
\hline Mean & 16.85 \\
Median & 17 \\
Mode & 16 \\
Std. Deviation & 1.387 \\
Range & 5 \\
Minimum & 14 \\
Maximum & 19 \\
\hline
\end{tabular}

Dari data di atas dapat dideskripsikan tingkat Keterampilan Teknik Dasar Passing pada Permainan Sepakbola di Puslat Pandanaran Boyolali dengan rerata sebanyak 16.85, nilai tengah sebanyak 17, nilai yang seringkali muncul sebanyak 16 serta simpangan baku sebesar 1.387. Sedangkan skor tertinggi 19 serta skor terendah 14. dari hasil tes maka dapat dikategorikan tingkat Keterampilan Teknik Dasar Passing pada Permainan Sepakbola di Puslat Pandanaran Boyolali. Perhitungan tersebut disajikan pada tabel sebagai berikut:

Tabel 2. Kategorisasi Keterampilan Teknik Dasar Passing Dalam Permainan Sepakbola Di Puslat Pandanaran Boyolali

\begin{tabular}{cccc} 
Interval Kelas & Frekuensi & Persentase (\%) & Kategori \\
\hline $\mathrm{X}>18,93$ & 4 & 20 & Baik Sekali \\
$17,54<\mathrm{X} \leq 18,93$ & 1 & 5 & Baik \\
$16,16<\mathrm{X} \leq 17,54$ & 6 & 30 & Cukup \\
$14,77<\mathrm{X} \leq 16,16$ & 8 & 40 & Kurang \\
$\mathrm{X} \leq 14,77$ & 1 & 5 & Kurang Sekali \\
\hline
\end{tabular}

Dari tabel di atas dapat diketahui bahwa tingkat Keterampilan Teknik Dasar Passing Dalam Permainan Sepakbola Pada Siswa Puslat Pandanaran Boyolali dapat dikatakan pada kategori cukup baik hal ini dapat disimpulkan menurut tabel pengkategorian diatas yang dimana pada kategori baik sekali ada 4 siswa atau 20\%, kategori baik ada 1 siswa atau 5\%, kategori cukup ada 6 siswa atau 30\%, kategori kurang ada 8 siswa atau 40\%, dan pada kategori kurang sekali ada 1 siswa atau $5 \%$. 


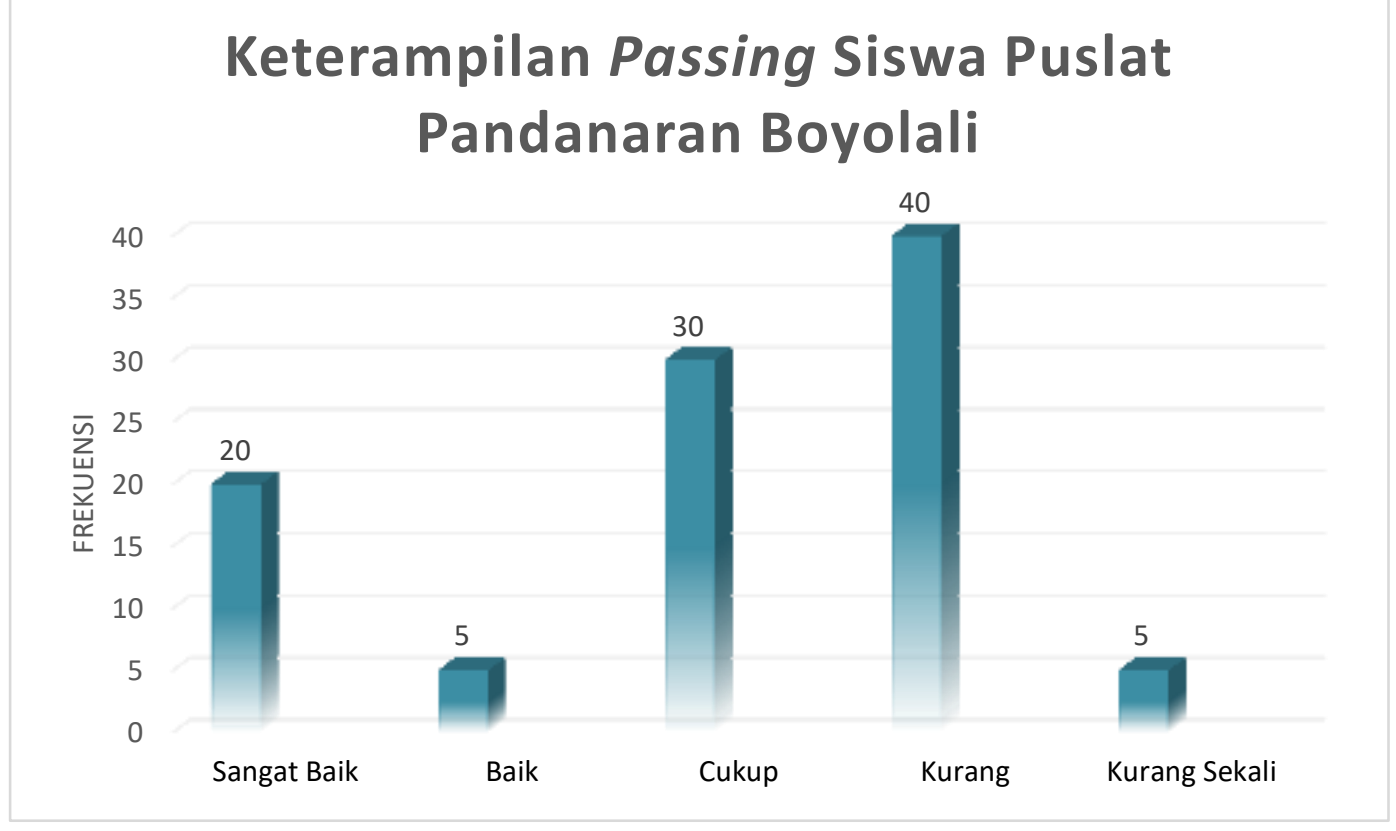

Grafik 1. Diagram Batang Keterampilan Teknik Dasar Passing Dalam Permainan Sepakbola Di Puslat Pandanaran Boyolali

Dari hasil penelitian yang dilakukan tentang tingkat Keterampilan Teknik Dasar Passing Dalam Permainan Sepakbola Di Puslat Pandanaran Boyolali diperoleh data dengan nilai 14 terdapat 1 siswa, nilai 15 terdapat 1 siswa, nilai 16 terdapat 7 siswa, nilai 17 terdapat 6 siswa, nilai 18 terdapat 1 siswa, dan nilai 19 terdapat 4 siswa. Dengan hasil data tersebut maka diperoleh data dengan rerata sebesar 16.85, nilai tengah sebesar 17 , nilai yang sering muncul sebesar 16 dan simpangan baku sebesar 1.387. Sedangkan skor tertinggi sebesar 19 dan skor terendah sebesar 14. Pada kategorisasi tingkat keterampilan passing dalam permainan sepakbola di puslat pandanaran boyolali pada kategori baik sekali yaitu nilai siswa lebih dari 18.93, kategori baik yaitu nilai siswa antara 17.54 sampai 18.93, kategori cukup yaitu nilai siswa antara 16.16 sampai 17.54 , kategori kurang yaitu nilai siswa antara 14,77 sampai 16.16, dan pada kategori kurang sekali yaitu nilai siswa kurang dari sama dengan 14.77. Dengan hasil tersebut maka diperoleh data dengan kategori baik sekali terdapat 4 siswa yaitu dengan nilai 19 dengan persentase $20 \%$, kategori baik terdapat 1 siswa yaitu dengan nilai 18 dengan persentase 5\%, kategori cukup terdapat 6 siswa yaitu dengan nilai 17 dengan persentase $30 \%$, kategori kurang terdapat 8 siswa yaitu dengan nilai 167 siswa dan dengan nilai 151 siswa dengan persentase $40 \%$, serta pada kategori kurang sekali terdapat 1 siswa yaitu dengan nilai 14 dengan persentase 5\%. Maka dari itu tingkat keterampilan teknik dasar passing pada permainan sepakbola di Puslat Pandanaran Boyolali dapat dikatakan pada kategori cukup baik.

Dalam instrument tes pengambilan data keterampilan teknik dasar passing dalam sepakbola pada siswa puslat pandanaran ini terdapat 4 proses penilaian yaitu pada sikap awal, pelaksanaan, sikap akhir, dan hasil passing. Pada saat sikap awalan siswa mayoritas mendapat nilai 5 atau sempurna yaitu 15 siswa dan 5 siswa mendapat nilai 4 . Hal ini dapat disimpulkan bahwa pada bagian sikap awalan masuk pada kategori baik sekali dan ke 5 siswa yang mendapat nilai 4 tersebut memiliki kesalahan yang sama pada saat awalan melakukan tendangan yaitu posisi kaki yang digunakan untuk menahan keseimbangan tubuh tidak berada disamping bola. Pada saat sikap pelaksanaan dalam proses melakukan passing masih banyak yang melakukan kesalahan yang dimana terdapat 9 siswa yang mendapatkan nilai 4 dan untuk kesalahan yang dilakukannya mayoritas pada saat menendang yaitu lutut kurang 
ditekuk. Hal ini sesuai dengan prosedur teknik dasar melakukan passing atau teknik mengoper bola. Pada bagian sikap akhir inilah banyak siswa yang melakukan kesalahan, hal ini dapat dilihat dari hasil penilaian pada sikap akhir yang dilakukan oleh siswa yang menunjukkan bahwa ada 6 siswa yang mendapatkan nilai sempurna atau nilai 5, 6 siswa yang mendapatkan nilai 4, 5 siswa yang mendapatkan nilai 3, 1 siswa yang mendapatkan nilai 2, dan 2 siswa yang mendapatkan nilai 1. Pada bagian sikap akhir ini mayoritas siswa melakukan kesalahan yaitu pada saat kaki yang digunakan untuk menendang bola tidak mendarat sedikit di depan kaki tumpu dan berat badan tidak dipindahkan ke depan.

Pada bagian hasil passing ini sangat dipengaruhi oleh ketiga faktor tersebut yaitu sikap awal, pelaksanaan, dan sikap akhir. Selain itu juga faktor lapangan sangat berpengaruh sekali pada hasil passing ini. Hal ini dapat dilihat dari nilai hasil passing tersebut yaitu 4 siswa mendapatkan nilai 5, 11 siswa mendapatkan nilai 4, 4 siswa mendapatkan nilai 3, dan 1 siswa mendapatkan nilai 2. Maka dari itu dapat disimpulkan bahwa pada bagian hasil passing ini siswa tergolong dalam kategori cukup. Pada hasil passing ini kesalahan yang dilakukan oleh siswa mayoritas pada arah bola yang ditendang tidak lurus kedepan dan bola yang dihasilkan tidak mendatar menyusur tanah. Dengan pertanyataan diatas dapat disimpulkan bahwa tes keterampilan teknik dasar passing dalam sepakbola yang dilakukan di Puslat Pandanaran Boyolali sikap awal, pelaksanaan, dan sikap akhir sangat berpengaruh terhadap hasil passing yang dilakukan siswa. Maka dari itu teknik dasar passing dalam sepakbola harus ditekankan, dilakukan, dan harus diulang-ulang untuk memperoleh hasil yang maksimal, kualitas passing seseorang dapat menunjang pemainan yang baik yang dimana akan lebih mudah menyusun serangan apabila passing atau aliran bolanya baik dan dengan adanya passing yang baik pemain dapat berkerjasama untuk memasuki area pertahanan lawan dan dapat mencetak gol, karena pada dasarnya pemainan sepakbola bola itu memiliki tujuan utama yaitu mencetak gol. Pada teknik dasar passing dalam permainan sepakbola terdapat beberapa faktor yang mempengaruhi tingkat keterampilan passing salah satunya yaitu impact atau perkenaan kaki pada bola saat melakukan passing, pada faktor impact tersebut harus sesuai dengan arah atau tujuan yang diinginkan oleh pengumpan seperti passing menggunakan kaki bagian dalam yang digunakan untuk mengoper jarak pendek, passing menggunakan kaki bagian luar untuk mengoper bola dengan tujuan bola melengkung keluar, dan passing kaki bagian punggung atau kura-kura kaki yang digunakan untuk mengoper bola dengan jarak yang cukup jauh sehingga bola yang dihasilkan melambung. Selain itu faktor yang mempengaruhinya yaitu proses belajar mengajar yang dimana siswa tersebut dapat menjalankan materi yang diberikan oleh pelatih dengan baik sesuai dengan metode yang diterapkan oleh pelatih. Selain itu faktor pribadi siswa masing-masing siswa juga sangat berpengaruh hal ini dapat dilihat dari sifat individu yang dimiliki siswa berbedabeda, baik dalam hal fisik, mental, maupun emosional. Serta faktor situasional juga berpengaruh terhadap keterampilan siswa, karena setiap lingkungan siswa memiliki keadaan atau situasi yang berbeda-beda(Ma'mun \& Saputra, 2000).

Keterampilan teknik dasar passing ini tidak lepas dari kegiatan latihan yang dilakukan oleh siswa puslat pandanaran boyolali. Dimana terdapat kelemahan pada penelitian ini dengan adanya latihan tidak selalu full team. Peningkatan keterampilan teknik dasar passing dapat dilakukan dengan latihan yang diberikan oleh pelatih, selain itu juga dapat diberikan sesi game diakhir latihan. Dengan adanya sesi game diakhir latihan, siswa dapat memiliki gambaran tentang kemampuan teknik dasar passing yang mereka miliki. Sehingga dengan mengikuti latihan dengan baik dapat menjadi sarana untuk meningkatkan keterampilan passing siswa. Karena pada dasarnya sekolah sepakbola atau pusat pelatihan sepakbola adalah suatu lembaga yg memberikan pengetahuan serta mengajarkan tentang teknik dasar sepakbola dan keterampilan bermain sepakbola pada anak mulai dari cara serta penguasaan teknik-teknik sepakbola dengan baik dan benar serta puslat bisa dikatakan sebagai fasilitas 
atau wadah bagi siswa sekolah sepakbola untuk menjaring minat serta bakat anak dalam bermain sepakbola.

\section{Simpulan}

Berdasarkan uraian hasil penelitian tingkat keterampilan teknik dasar passing dalam permainan sepakbola siswa Puslat Pandanaran Boyolali dalam kategori cukup, hal ini selaras dengan capaian yang diperoleh oleh siswa yaitu pada kategori baik sekali memiliki presentase $20 \%$, kategori baik presentase 5\%, kategori cukup presentase 30\%, kategori kurang presentase $40 \%$, dan kategori kurang sekali $5 \%$.

\section{Daftar Pustaka}

Arwandi, J., \& Ardianda, E. (2018). Latihan Zig-Zag Run Dan Latihan Shuttle Run Berpengaruh Terhadap Kemampuan Dribbling Sepakbola. Jurnal Performa Olahraga, 3(01), 32.

Afandi, A., \& Faisal, M. (2020). Upaya Meningkatkan Teknik Juggling Permainan Futsal Dengan Media Alat Bantu. Jurnal Porkes, 3(2), 142-148.

Hetrina, H., Prastowo, D., \& Suyanto, S. (2020). Analisis Faktor-faktor yang Mempengaruhi Keputusan Hedging dengan Kualitas Laba Sebagai Moderasi pada Industri Manufaktur di Indonesia Tahun 2014-2017. Jurnal Riset Akuntansi Terpadu, 13(2), $157-172$.

Hutajulu, P. T. (2013). MENINGKATKAN KETRAMPILAN TEKNIK DASAR PASSING SEPAKBOLA MELALUI PENGEMBANGAN MODEL BELAJAR PERMAINAN PADA SISWA PUTRA KELAS V SD. JURNAL OLAHRAGA PAPUA, 1(1).

Hulfian, L. (2020). Latihan Kelincahan Boomerang Run Dapat Meningkatkan Keterampilan Menggiring Bola Dalam Permainan Futsal. Jurnal Porkes, 3(1), 9-14.

Indarto, P. (2019). MAHIR BERMAIN SEPAKBOLA (R. Saifullah \& M. Fatoni (ed.); 1 ed.). Muhammadiyah University Press.

Joseph, L. ., \& Agusta, W. (2016). Sepakbola (2 ed.). Rajawali Pers.

Jusran, S. (2021). Analisis Komponen Fisik Terhadap Kemampuan Shooting. Jurnal Porkes, 4(1), 55-61.

Komarudin, K. (2017). Analisis kesalahan siswa dalam pemecahan masalah matematika pada materi peluang berdasarkan high order thinking dan pemberian scaffolding. Jurnal Darussalam: Jurnal Pendidikan, Komunikasi Dan Pemikiran Hukum Islam, 8(1), 202-217.

Ma'mun, A., \& Saputra, M. P. D. Y. M. (2000). Perkembangan gerak dan belajar. Direktorat Jenderal Pendidikan Dasar dan Menengah.

Noviada, G., Kanca, I. N., \& Darmawan, G. E. B. (2014). Metode pelatihan taktis passing berpasangan statis dan passing sambil bergerak terhadap keterampilan teknik dasar passing control bola futsal. Jurnal Pendidikan Kepelatihan Olahraga Undiksha, 2(1).

Pelamonia, S. P., \& Hutapea, A. P. (2020). Pengaruh Latihan Passing 5, 10, 15 Meter Terhadap Ketepatan Passing Sepakbola. Jurnal Porkes, 3(2), 103-109.

Satori, D. (n.d.). an dan Aan Komariah. 2014. Metodologi penelitian kualitatif.

Soniawan, V., \& Irawan, R. (2018). Metode Bermain Berpengaruh Terhadap Kemampuan

Sugiarto, T., Tomi, A., \& Fauzi, I. A. (2020). Upaya meningkatkan keterampilan teknik dasar passing futsal menggunakan metode drill. Spor

Saputra, S. Y., \& Suarti, N. K. A. (2019). Pengaruh Gaya Mengajar Resiprokal Terhadap Hasil Menendang Bola Dalam Permainan Sepak Bola. Jurnal Porkes, 2(1), 06-12.

Long Passing Sepakbola. Jurnal Performa Olahraga, 3(01), 42. 
Quddus, A., Dinata, K., \& Daniyantara, D. (2018). Pengaruh Variasi Latihan Terhadap Peningkatan Keterampilan Bermain Sepak Bola Pada Club Putra Baja Fc. Jurnal Porkes, 1(1), 21-26.

Unnithan, V., White, J., Georgiou, A., Iga, J., Unnithan, V., White, J., \& Drust, B. (2017). Talent identification in youth soccer Talent identification in youth soccer. Journal of Sports Sciences, 414.

Wicaksono, P. N., Kusuma, I. J., Festiawan, R., Widanita, N., \& Anggraeni, D. (2020). Penerapan pendekatan saintifik terhadap pembelajaran pendidikan jasmani materi teknik dasar passing sepak bola. Jurnal pendidikan jasmani Indonesia, 16(1), 41-54. 